\title{
3-(3,4-Dimethoxyphenyl)-5-(2-fluorophenyl)-1-phenyl- 4,5-dihydro- $1 H$-pyrazole
}

\author{
Adel Zamri ${ }^{1}$, Hilwan Y. Teruna ${ }^{1}\left(\mathbb{D}\right.$, Sri Wulansari ${ }^{1}$, Noval Herfindo ${ }^{1}{ }^{(0}$, Neni Frimayanti ${ }^{2}$ \\ and Ihsan Ikhtiarudin ${ }^{2, *}$ \\ 1 Department of Chemistry, Faculty of Mathematics and Natural Sciences, Universitas Riau, Jalan H.R. \\ Subrantas KM. 12.5, Pekanbaru 28293, Indonesia; adel.zamri@lecturer.unri.ac.id (A.Z.); \\ hyteruna@lecturer.unri.ac.id (H.Y.T.); sri.wulansari@student.unri.ac.id (S.W.); \\ novalherfindo@gmail.com (N.H.) \\ 2 Department of Pharmacy, Sekolah Tinggi Ilmu Farmasi (STIFAR) Riau, Jalan Kamboja, Pekanbaru 28293, \\ Indonesia; nenifrimayanti@gmail.com \\ * Correspondence: ihsanikhtiarudin@stifar-riau.ac.id; Tel.: +62-0761-588-007
}

Received: 9 October 2019; Accepted: 8 November 2019; Published: 12 November 2019

\begin{abstract}
A new analogue of fluorinated pyrazoline (compound 1) has been synthesized via one-pot three-component reaction in a sealed-vessel reactor, Monowave 50. The structure of compound 1 has been established by spectroscopy analysis, including UV, FT-IR, HRMS, ${ }^{1} \mathrm{H}$ and ${ }^{13} \mathrm{C}$ NMR spectroscopy. Based on the in silico studies, this compound showed a good potential as an inhibitor for dengue virus type 2 (DEN2) NS2B/NS3 serine protease and can be used as a reference in the next design of an antidengue virus.
\end{abstract}

Keywords: fluorinated pyrazolines; in silico study; sealed-vessel reactor; Monowave 50; one-pot three-component reaction; DEN2 NS2B/NS3 protease

\section{Introduction}

Fluorine is an important element in the chemical industry [1]. The introduction of a fluorine atom into an organic molecule may lead to significant influences on its physical properties [2]. The uniqueness of their properties makes fluorinated organic compounds an interesting option to synthesize and evaluate their pharmacological effects [3].

Some fluorinated compounds (e.g., fluorinated pyrazolines) have been reported for their significant biological activities, such as antibacterial, antifungal, antitubercular [2], anticancer [4], antiproliferative [5], and monoamine oxidase inhibitory activities [6]. Generally, these compounds are prepared from substituted acetophenones and benzaldehydes via two-step reactions. The first is the synthesis of fluorinated chalcone through Claisen-Schmidt condensation, then the second is the synthesis of fluorinated pyrazoline through intermolecular cyclization of fluorinated chalcone with a hydrazine or its derivatives [7] such as thiosemicarbazide [4], phenylhydrazine [8], hydrazine hydrate [9], halogenated phenylhydrazine [10], and 3,4,5-trimethoxybenzohydrazide [11]. Other researchers have also reported one-pot synthesis of pyrazolines from various starting materials and methods such as from 3-butynol and substituted phenylhydrazine under reflux condition [12], from substituted acetophenone, benzaldehyde, and phenylhydrazine under reflux condition $[13,14]$ and through the formal $[4+1]$ annulation reaction of 3-bromooxindoles and in situ-derived 1,2-diaza-1,3-dienes by stirring at room temperature [15]. In addition, it has also been reported that the one-pot synthesis of pyrazolines can be performed by reacting pyridine based chalcone and hydrazine hydrate under $300 \mathrm{~W}$ microwave irradiation [16]; by reacting substituted chalcone, hydrazine hydrate, and acetic anhydride under $550 \mathrm{~W}$ microwave irradiation [17]; and by reacting 
substituted pyrazole, formaldehyde, and $\beta$-diketone under $300 \mathrm{~W}$ microwave irradiation [18]. However, the use of a sealed-vessel reactor in one-pot synthesis of pyrazoline from substituted benzaldehyde, acetophenone, and phenylhydrazine has not been reported previously.

In this work, we report the synthesis of a new analogue of fluorinated pyrazoline (compound 1) through a one-pot three-component reaction by heating the mixture of $3^{\prime}, 4^{\prime}$-methoxyacetophenone, 2-fluorobenzaldehyde, and phenylhydrazine in a sealed-vessel reactor, Monowave 50. The applied heating technology (a tight-fitting, electrically heated metal heating jacket) enables to mimick the heating rates of a microwave reactor in the applicable operation volume. Monowave 50 enables synthesis multiple times faster than traditional stirrer hot-plate setups while delivering the performance of a microwave reactor. Then, the molecular docking and Molecular Dynamic (MD) simulation have been also performed to evaluate the potency of compound 1 as an inhibitor for DEN2 NS2B/NS3 serine protease.

\section{Results and Discussion}

\subsection{Synthesis of Compound 1}

The synthesis of compound $\mathbf{1}$ was conducted by modification from previously original one-pot method under reflux condition $[13,14]$. In this work, the one-pot three-component reaction was performed in the presence of $2 \mathrm{~mL}$ of $10 \%$ sodium hydroxide solution as the catalyst in a sealed-vessel reactor, Monowave 50 at $80^{\circ} \mathrm{C}$ for $10 \mathrm{~min}$, as depicted in Figure 1.

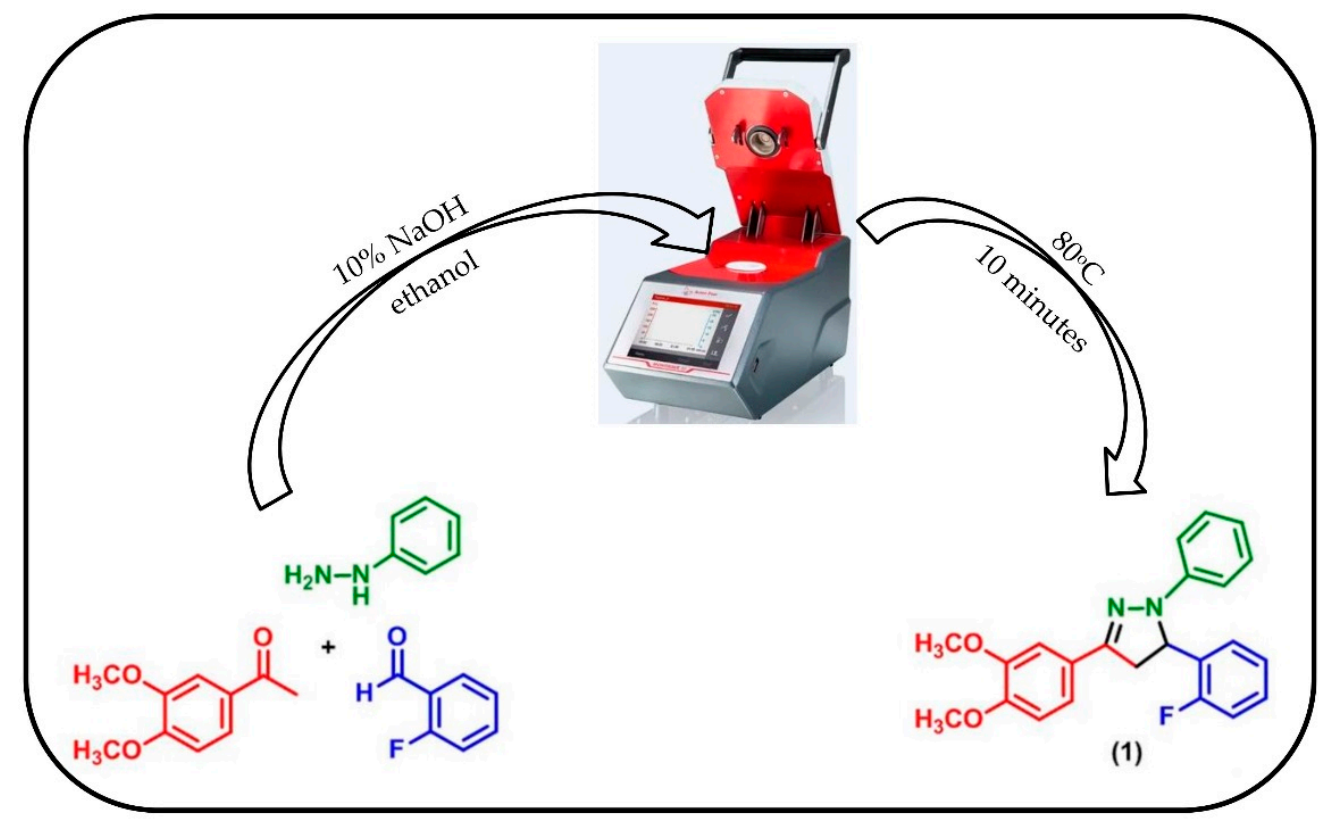

Figure 1. One-pot synthesis of compound 1 in a sealed-vessel reactor, Monowave 50.

The UV spectrum of compound $\mathbf{1}$ was recorded in ethanol and showed $\lambda_{\max }(\mathrm{nm})$ at 228 and 355. These absorptions indicated the presence of conjugated double bonds of the aromatic rings of 1. The FT-IR spectrum showed absorption bands $\left(v, \mathrm{~cm}^{-1}\right)$ at 3083 and 3020 . These absorptions are due to the asymmetrical and symmetrical vibrations of aromatic $\mathrm{C}-\mathrm{H}$ bonds, respectively, and they were confirmed by the appearance of aromatic proton signals around $\delta$ (ppm) 7.52-6.80 and aromatic carbon signals around $\delta 160.73-108.16$ in the ${ }^{1} \mathrm{H}$ and ${ }^{13} \mathrm{C}$ NMR spectrum, respectively.

The presence of both methoxy groups in the aromatic ring were shown by the absorption bands of asymmetrical and symmetrical vibrations of aliphatic $\mathrm{C}-\mathrm{H}$ bonds at $v 2927$ and 2845, respectively, and they were confirmed by the appearance of two singlet signals at $\delta 3.99(3 \mathrm{H})$ and $3.91(3 \mathrm{H})$ in the ${ }^{1} \mathrm{H}$ NMR spectrum and a singlet signal at $\delta 55.94$ in the ${ }^{13} \mathrm{C}$ NMR spectrum. 
Other aliphatic proton signals at $\delta 3.12,3.89$, and 5.55 in the ${ }^{1} \mathrm{H}$ NMR spectrum indicated the presence of methylene and methyne protons in the pyrazoline ring, respectively. The coupling constant of $17.00 \mathrm{~Hz}$ was due to the geminal coupling of $\mathrm{H}_{4 \mathrm{a}}$ and $\mathrm{H}_{4 \mathrm{~b}}$ in methylene group. The presence of these two groups were also confirmed by aliphatic carbon signals at $\delta 42.39$ and 57.64 in the ${ }^{13} \mathrm{C}$ NMR spectrum.

The absorption band at $v 1599$ in the FT-IR spectrum indicated the presence of the $\mathrm{C}=\mathrm{N}$ group and this was confirmed by ${ }^{13} \mathrm{C}$ NMR spectra by the appearance of a signal at $\delta 149.99$. The absorption bands at $\vee 1119$ in the FT-IR spectrum indicated the presence of C-F groups and they were confirmed by seven split signals at aromatic carbons area of $\delta 159.76,129.13,129.08,127.55,124.77,115.62$, and 57.64 in the ${ }^{13} \mathrm{C}$ NMR spectra. These splittings were due to the $1-4$ bonds' $J$ couplings of ${ }^{13} \mathrm{C}$ to ${ }^{19} \mathrm{~F}[19,20]$. In this case, the observed ${ }^{1} J_{\mathrm{C}-\mathrm{F}}$ (a) was $244 \mathrm{~Hz} ;{ }^{2} J_{\mathrm{C}-\mathrm{F}}$ (b) and (c) were 21.3 and $13.8 \mathrm{~Hz}$, respectively; ${ }^{3} J_{\mathrm{C}-\mathrm{F}}(\mathrm{d})$, (e), and (f) were $8.75,3.75$, and $2.5 \mathrm{~Hz}$, respectively; and ${ }^{4} J_{\mathrm{C}-\mathrm{F}}(\mathrm{g})$ was $3.1 \mathrm{~Hz}$, as shown in Figure 2. More information about the spectra are provided in the Supplementary Materials.

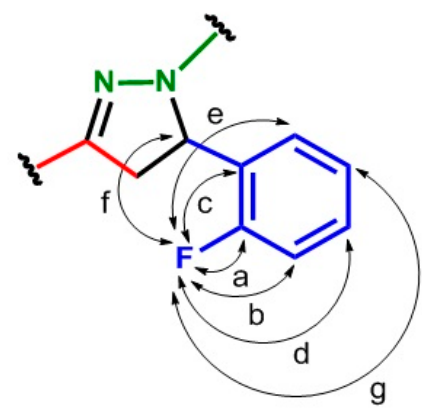

Figure 2. The ${ }^{1-4} J_{C-F}$ in fluorophenyl ring of $\mathbf{1}$.

\subsection{In Silico Studies of Compound $\mathbf{1}$}

The molecular docking study and molecular dynamic simulation were performed to evaluate the potency of the inhibitory activity of compound 1 against dengue virus DEN2 NS2B/NS3 protease. The spatial arrangement of compound $\mathbf{1}$ is illustrated in Figure 3 and the docking results are presented in Table 1. Based on the molecular docking results, compound $\mathbf{1}$ was able to build two hydrogen bonds. First, this compound is able to build a hydrogen bond with His51 residue (i.e., active site) and second, this compound is also capable of building a hydrogen bond with Arg74 residue. In addition, compound 1 also has van der Waals interaction with one of the active site's residues i.e., Asp75, indicating the importance of this residue in the formation of van der Waals binding pocket. In addition, compound 1 was also able to build hydrophobic interactions with His51 and Arg74 residues.

Table 1. Molecular docking results.

\begin{tabular}{|c|c|c|c|c|}
\hline \multirow{2}{*}{ Molecules } & \multirow{2}{*}{$\begin{array}{c}\text { Estimated Binding } \\
\text { Free Energy (kcal/mol) }\end{array}$} & \multicolumn{3}{|c|}{ Interactions } \\
\hline & & Hydrogen Bonds & Van der Waals & Hydrophobic \\
\hline Compound 1 & -59.98 & His51, Arg74 & Asp75 & His51, Arg74 \\
\hline Panduratin A & $-57.80^{a}$ & His51, Gly153 & Gly51 & - \\
\hline
\end{tabular}




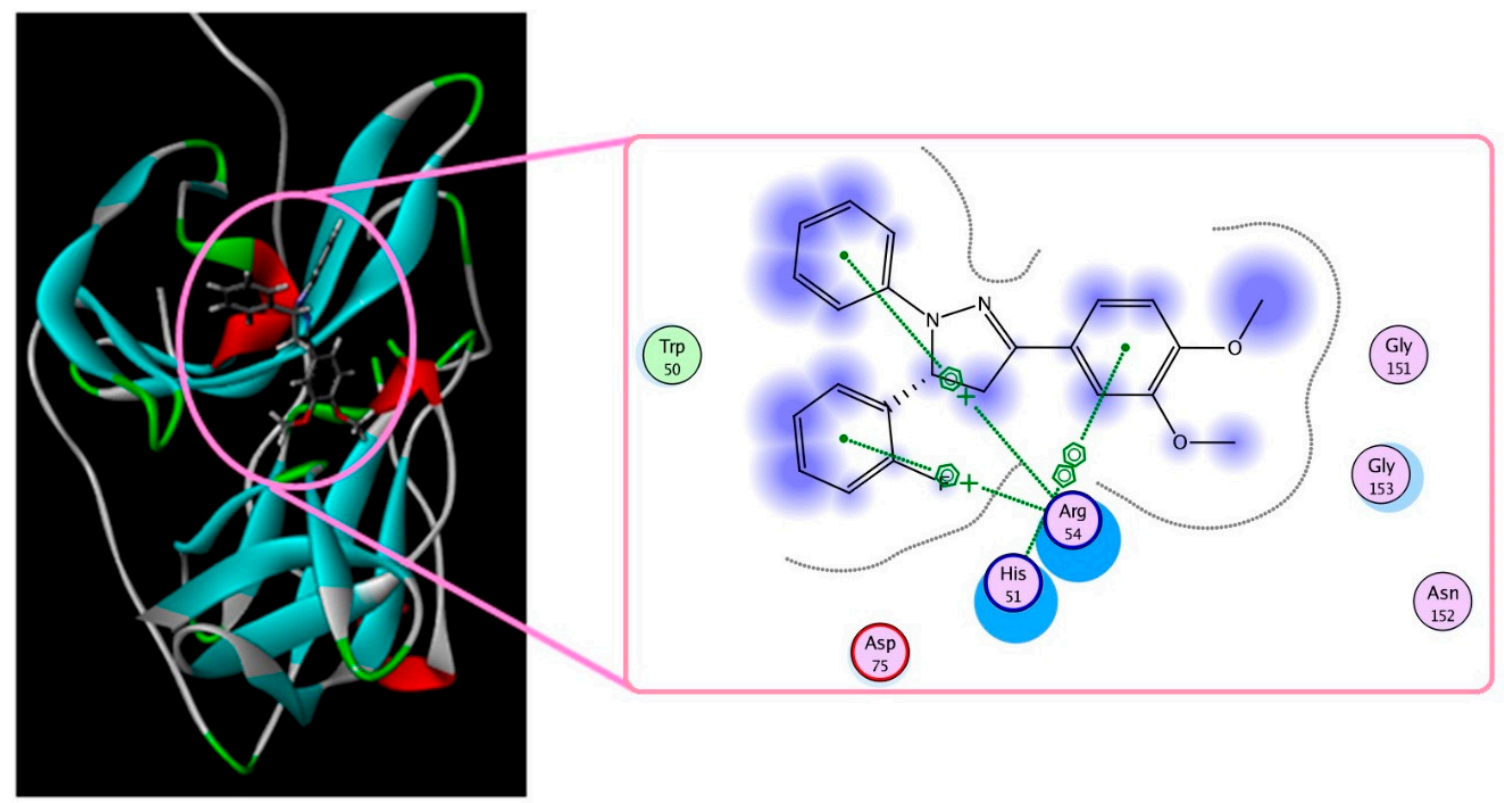

Figure 3. Spatial arrangement of compound 1.

Based on Table 1, compound 1 showed a similar interaction with panduratin A as a positive control (reference compound). Both compounds have similar interactions with His51 residue through a hydrogen bonding formation. However, compound $\mathbf{1}$ also has van der Waals interaction with another active site i.e., Asp75. This may have caused the calculation of estimated binding free energy of compound 1 to be slightly lower than panduratin A. Based on the calculation, it is likely the reason that compound 1 can be assumed to be a good inhibitor for dengue virus DEN2 NS2B/NS3 protease.

Molecular dynamic simulation was performed to ensure the hydrogen bonding and another interaction between ligand and protein $[20,22]$ were still maintained. The MD simulation was started using the energy minimum with high stability, the system fluctuated around the initial conformation and the ligand continued to have initial binding modes. The MD simulation was performed to see the affinity of compound 1 to the binding site of NS2B/NS3 protease. The visualization of the MD simulation is depicted in Figure 4.

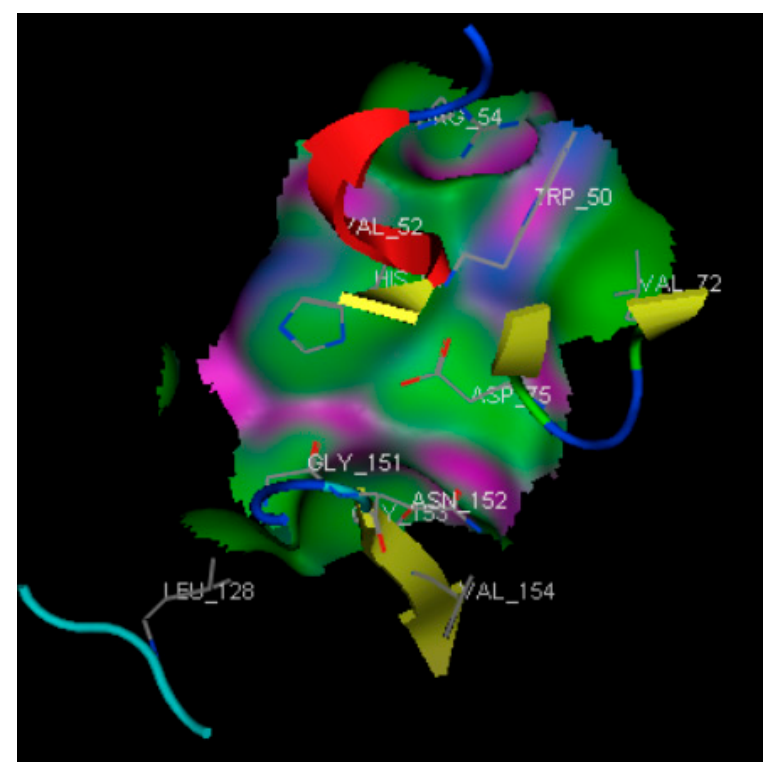

Figure 4. Visualization of MD simulation of compound $\mathbf{1 .}$ 
Based on Figure 4, it seems that compound 1 still has hydrogen bonding with His51 and also van der Waals interaction with Asp75 residue. Unfortunately, after the MD simulation this compound did not interact with His51 and Arg74 via hydrophobic interaction anymore. The molecular docking study and MD simulation showed that the binding affinity of compound $\mathbf{1}$ was able to construct the hydrogen bond, van der Waals, and hydrophobic interactions with some important residues in the protein. This demonstrated that compound $\mathbf{1}$ has good potential as an inhibitor and can be used and chosen as a reference in the next design of antidengue virus type-2 (DEN2 NS2B/NS3).

\section{Materials and Methods}

\subsection{General Information}

The materials used in this work were $3^{\prime}, 4^{\prime}$-dimethoxyacetophenone, 2-fluorobenzaldehyde, phenylhydrazine, sodium hydroxide, and some organic solvents, such as ethanol and $n$-hexane, and were produced by Merck or Sigma-Aldrich. The synthesis reaction was carried out using a sealed-vessel reactor (Anton-Paar Monowave 50). Melting point was determined on a Fisher-Johns apparatus (Fisher Scientific) (uncorr). TLC analysis was carried out using $\mathrm{GF}_{254}$ (Merck Millipore, Darmstadt, Germany) under a UV Lamp 254/366 nm (Camag ${ }^{\mathrm{TM}}$ ). The HPLC analysis was performed in a Shim-pack VP-ODS column $(250 \times 4.6 \mathrm{~mm})$, with a mixture of acetonitrile and water as the mobile phase in a gradient system for $25 \mathrm{~min}$, flow rate of $0.75 \mathrm{~mL} / \mathrm{min}$. UV SPD 20AD detector was used on Ultra Fast Liquid Chromatography (UFLC) Prominance-Shimadzu LC Solution (Shimadzu Corporation, Kyoto, Japan). UV spectrum was recorded on Genesys ${ }^{\mathrm{TM}} 10 \mathrm{~S}$ UV-Visible spectrophotometer (Thermo Scientific ${ }^{\mathrm{TM}}$, Waltham, MA, USA). FT-IR spectrum was recorded in $\mathrm{KBr}$ powder on a Shimadzu ${ }^{\circledR}$ FT-IR Prestige-21 spectrophotometer (Shimadzu Corporation, Kyoto, Japan). Mass spectrum was recorded on High Resolution-Electron Spray Ionization-Time-of-Flight Mass Spectrometry (HR-ESI-TOFMS). ${ }^{1} \mathrm{H}$ and ${ }^{13} \mathrm{C}-\mathrm{NMR}$ spectrum were recorded on an Agilent ${ }^{\circledR}$ (Agilent Technologies, Santa Clara, CA, USA) at $500 \mathrm{MHz}$ and $125 \mathrm{MHz}$, respectively.

\subsection{Synthesis of 3-(3,4-dimethoxyphenyl)-5-(2-fluorophenyl)-1-phenyl-4,5-dihydro-1H-pyrazole (1)}

The synthesis of compound $\mathbf{1}$ was conducted by a modification of previous methods $[13,14]$. $3^{\prime}, 4^{\prime}$-dimethoxyacetophenone ( $\left.0.5 \mathrm{mmol}\right), 2$-fluorobenzaldehyde $(0.5 \mathrm{mmol})$, and phenylhydrazine $(2 \mathrm{mmol})$ were dissolved in ethanol absolute $(5 \mathrm{~mL})$ in a pressure tube with a stirbar and $2 \mathrm{~mL}$ of $10 \%$ sodium hydroxide was added. The mixture was heated in a sealed-vessel reactor, Anton-Paar Monowave 50 at $80{ }^{\circ} \mathrm{C}$ for $10 \mathrm{~min}$. The reaction was monitored every $5 \mathrm{~min}$ of reaction by TLC analysis, until the reaction was completed. Then, the mixture was cooled in an ice bath for $24 \mathrm{~h}$ to afford precipitation and was filtered in vacuo, washed by cold $n$-hexane and allowed to dry in a desiccator. The crude product was recrystallized in hot ethanol to afford the pure product.

Compound 1 was obtained as a yellow solid in 57\% yield. The melting point was recorded at 138- $139^{\circ} \mathrm{C}$ (uncorr). The HPLC chromatogram showed a single peak at $t_{R}=19.2 \mathrm{~min}$. The UV spectrum in EtOH showed $\lambda_{\max }(\mathrm{nm})$ at 228 and 355. The FT-IR spectrum in $\mathrm{KBr}$ powder showed absorption bands $\left(\mathrm{cm}^{-1}\right)$ at 3083, 3020, 2927, 2845, 1599, 1516, 1247, 1143, and 1119. The mass of compound 1 in HR-ESI-TOFMS spectrum was $m / z=377.1612(100 \%)$ and was calculated as $\mathrm{C}_{23} \mathrm{H}_{22} \mathrm{~N}_{2} \mathrm{O}_{2} \mathrm{~F}$. The ${ }^{1} \mathrm{H}$ NMR spectrum was recorded in $\mathrm{CDCl}_{3}(500 \mathrm{MHz}): 7.51(\mathrm{~d}, 1 \mathrm{H}), 7.22(\mathrm{~m}, 4 \mathrm{H}), 7.12(\mathrm{dt}, 1 \mathrm{H}), 7.05(\mathrm{~m}$, $4 \mathrm{H}), 6.85(\mathrm{~d}, 1 \mathrm{H}), 6.80(\mathrm{dt}, 1 \mathrm{H}), 5.55(\mathrm{dd}, 1 \mathrm{H}), 3.99(\mathrm{~s}, 3 \mathrm{H}), 3.91(\mathrm{~s}, 3 \mathrm{H}), 3.89(\mathrm{dd}, 1 \mathrm{H}), 3.12(\mathrm{dd}, 1 \mathrm{H})$. The ${ }^{13} \mathrm{C}$ NMR spectrum was recorded in $\mathrm{CDCl}_{3}(125 \mathrm{MHz})$ : $159.76(\mathrm{~J}=244 \mathrm{~Hz}), 149.99,149.15,147.35$, $144.82,129.13(J=13.8 \mathrm{~Hz}), 129.08(\mathrm{~J}=8.75 \mathrm{~Hz}), 128.98,127.55(J=3.75 \mathrm{~Hz}), 125.65,124.77(J=3.75 \mathrm{~Hz})$, 119.11, 119.06, $115.62(J=21.3 \mathrm{~Hz}), 113.11,110.66,108.16,57.64,55.94,42.39$. Copies of the spectroscopy data of compound 1 (Figures S2-S6) are provided in the Supplementary Materials. 


\subsection{Molecular Docking Study and Molecular Dynamic Simulation}

Docking of compound 1 was performed using the Molecular Operating Environment (MOE) software package [21]. Protein was downloaded from a protein database with PDB ID: 2FOM [23]. The docking process was initiated with ligand and protein preparation. Protein preparation was begun with adding a hydrogen bond into the protein, for then backbone atom was minimized. All ligands have to minimized before docking. The simulated annealing method with CHARMM27 (Chemistry at Harvard Macromolecular Mechanics) force field was used for docking, all of this was integrated in the MOE software package (Chemical Computing Group Inc.). A grid box was measured with $26.69 \AA \times 28.69 \AA \times 25.05 \AA$ dimensions along the $\mathrm{x}, \mathrm{y}, \mathrm{z}$ axes. Conformation of the complex ligand-protein with the lowest docked energy was then chosen and geometry was minimized to a gradient $0.01 \mathrm{kcal} / \mathrm{mol} / \AA$ using the same force field. The minimization processes were performed by relaxing the structure step by step as described below. It started with minimization with the heavy atom fixed followed by minimization with the backbone atom fixed and minimization with alpha carbons fixed, and finally minimization of all atoms was carried out.

\section{Conclusions}

In summary, we have synthesized a new analogue of fluorinated pyrazoline, 3-(3,4-dimethoxyphenyl)-5-(2-fluorophenyl)-1-phenyl-4,5-dihydro- $1 H$-pyrazole (1) via one-pot, three-component reaction in a sealed-vessel reactor. All the spectroscopic data agreed with the structure of product that was expected. The study showed that the binding affinity of compound 1 was able to contruct the hydrogen bond, van der Waals, and hydrophobic interactions with some important residues in the protein, demonstrating that compound 1 to possesses good potential as an inhibitor and can be chosen as a reference in the next design of antidengue virus type-2 (DEN2 NS2B/NS3).

Supplementary Materials: The following are available online, Figure S1: HPLC chromatogram of compound 1, Figure S2: TOF HRMS ES+ spectrum of compound 1, Figure S3: ${ }^{1} \mathrm{H}$ NMR spectra of compound 1, Figure S4: ${ }^{1} \mathrm{H}$ NMR spectra of compound 1, expanded aromatic region, Figure S5: ${ }^{13} \mathrm{C}$ NMR spectra of compound 1, Figure S6:

${ }^{13} \mathrm{C}$ NMR spectra of compound 1, expanded aromatic region.

Author Contributions: Design of all experiments, A.Z.; Experimental synthetic work, A.Z., S.W. and N.H.; Interpretation of spectroscopic data, H.Y.T. and I.I.; in silico studies, N.F. and I.I.; Literature research and writing of manuscript, I.I., A.Z. and N.F.; review and editing of manuscript, H.Y.T., N.F. and I.I.; All authors read and approved the final manuscript.

Funding: This work was funded by Direktorat Riset dan Pengabdian Masyarakat (DPRM) KEMENRISTEK DIKTI through Penelitian Dasar Unggulan Perguruan Tinggi (PDUPT) grant with contract number 751/UN.19.5.1.3/PT.01.03/2019.

Acknowledgments: We thank DPRM KEMENRISTEK DIKTI for funding this work. We also thank the Laboratory of Organic Synthesis, Department of Chemistry, Faculty of Mathematics and Natural Sciences, Universitas Riau for providing the synthesis facility and thank to PT. Equiva Ligand Indonesia for supplying the consumable Anton-Paar Monowave 50. Finally, We thank the Laboratory of Natural Product Pharmacy, Sekolah Tinggi Ilmu Farmasi Riau for providing the in silico study facility.

Conflicts of Interest: The authors declare no conflict of interest.

\section{References}

1. O'Hagan, D. Understanding organofluorine chemistry. An introduction to the C-F bond. Chem. Soc. Rev. 2008, 37, 308-319. [CrossRef] [PubMed]

2. Shelke, S.N.; Mhaske, G.R.; Bonifácio, V.D.B.; Gawande, M.B. Green Synthesis and anti-infective activities of fluorinated pyrazolines derivatives. Bioorg. Med. Chem. 2012, 22, 5727-5730. [CrossRef] [PubMed] 
3. Purser, S.; Moore, P.R.; Swallow, S.; Gouverneur, V. Fluorine in medicinal chemistry. Chem. Soc. Rev. 2008, 37, 320-330. [CrossRef] [PubMed]

4. Yang, W.; Hu, Y.; Yang, Y.S.; Zhang, F.; Zhang, Y.B.; Wang, X.L.; Tang, J.F.; Zhong, W.Q.; Zhu, H.L. Design, modification and 3D QSAR studies of novel naphthalin-containing pyrazolines derivatives with/without thiourea skeleton as anticancer agents. Bioorg. Med. Chem. 2013, 21, 1050-1063. [CrossRef] [PubMed]

5. Rao, B.S.; Akberali, P.M.; Holla, B.S.; Sarojini, B.K. Synthesis and studies of some new fluorine containing hydroxypyrazolines and $1 H$ pyrazoles as possible antipoliferative agents. J. Pharmacol. Toxicol. 2008, 3, 102-110. [CrossRef]

6. Koç, G.Ş.; Tan, O.U.; Uçar, G.; Yıldırım, E.; Erol, K.; Palaska, E. Synthesis and monoamine oxidase inhibitory activities of some 3-(4-fluorophenyl)-5-aryl-N-substituted-4,5-dihydro-(1H)-pyrazole-1-carbothioamide derivatives. Drug Res. 2014, 64, 591-598. [CrossRef] [PubMed]

7. Yusuf, M.; Jain, P. Synthetic and biological studies of pyrazolines and related heterocyclic compounds. Arab. J. Chem. 2014, 7, 553-596. [CrossRef]

8. Jasril, J.; Zamri, A.; Ikhtiarudin, I.; Teruna, H.Y. 5-(4-fluorophenyl)-3-(naphthalen-1-yl)-1-phenyl-4,5dihydro-1H-pyrazole. Molbank 2016, 2016, M891. [CrossRef]

9. Jagadhani, S.G.; Kundlikar, S.G.; Karale, B.K. Synthesis and characterization of some fluorinated 1,5-benzothiazepines and pyrazolines. Orient. J. Chem. 2015, 31, 601-604. [CrossRef]

10. Lu, B.; Zhang, J.; Wang, M.; Zhou, Y. Synthesis and Fluorescent Property of Pyrazoline Derivatives. Chin. J. Chem. 2012, 30, 1345-1350. [CrossRef]

11. Manivannan, C.; Santhi, N. Synthesis, characterization and antifugal activity of some fluorine containing 1,3,5-trisubstituted pyrazolines derivatives. World News Nat. Sci. 2017, 10, 86-94.

12. Alex, K.; Tillack, A.; Schwarz, N.; Beller, M. Zinc-Catalyzed Synthesis of Pyrazolines and Pyrazoles via Hydrohydrazination. Org. Lett. 2008, 10, 2377-2379. [CrossRef] [PubMed]

13. Hawaiz, F.E.; Hussein, A.J.; Samad, M.K. One-pot three-component synthesis of some new azo-pyrazoline derivatives. Eur. J. Chem. 2014, 5, 233-236. [CrossRef]

14. Hawaiz, F.E.; Chawishli, L.H.; Samad, M.K.; Mohamed, S.K. One Pot Synthesis and Characterization of Some New 1,3,5-Trisubstituted Pyrazoline Derivatives. J. Chem. Pharm. Res. 2017, 9, 185-190.

15. Chen, D.Z.; Xiao, W.J.; Chen, J.R. Synthesis of spiropyrazoline oxindoles by a formal [4+1] annulation reaction between 3-bromooxindoles and in situ- derived 1,2-diaza-1,3-dienes. Org. Chem. Front. 2017, 4, 1289-1293. [CrossRef]

16. Patel, N.B.; Shaikh, F.M.; Patel, H.R.; Rajani, D. Synthesis of 2-pyrazolines from pyridine based chalcone by conventional and microwave techniques: Their comparison and antimicrobial studies. J. Saudi Chem. Soc. 2016, 20, S451-S456. [CrossRef]

17. Thirunarayanan, G.; Sekar, K.G. Solvent-free one-pot cyclization and acetylation of chalcones: Synthesis of some 1-acetyl pyrazoles and spectral correlations of 1-(3-(3,4-dimethylphenyl)-5-(substituted phenyl)-4,5-dihydro-1H-pyrazole-1-yl) ethanones. J. Saudi Chem. Soc. 2016, 20, 661-672. [CrossRef]

18. Polo, E.; Ferrer-Pertuz, K.; Trilleras, J.; Quiroga, J.; Gutierrez, M. Microwave-assisted one-pot synthesis in water of carbonylpyrazolo [3,4-b]pyridine derivatives catalyzed by $\mathrm{InCl}_{3}$ and sonochemical assisted condensation with aldehydes to obtain new chalcone derivatives containing the pyrazolopyridinic moiety. RSC Adv. 2017, 7, 50044-50055. [CrossRef]

19. Guo, W.; Wong, T.C. Study of ${ }^{13} \mathrm{C}-{ }^{19} \mathrm{~F}$ and ${ }^{1} \mathrm{H}-{ }^{19} \mathrm{~F}$ couplings in some fluorinated aromatic compounds using two-dimensional ${ }^{13} \mathrm{C}-{ }^{1} \mathrm{H}$ chemical shift correlation spectroscopy with proton homonuclear decoupling. Magn. Res. Chem. 1986, 24, 75-79. [CrossRef]

20. Jasril, J.; Ikhtiarudin, I.; Zamri, A.; Teruna, H.Y.; Frimayanti, N. New fluorinated chalcone and pyrazoline analogs: Synthesis, docking and molecular dynamic studies as anti cancer agents. TJPS 2017, 41, 93-98.

21. Frimayanti, N.; Chee, C.; Zain, S.M.; Rahman, N.A. Design of new competitive dengue NS2B/NS3 protease inhibitors-A computational approach. Int. J. Mol. Sci. 2011, 12, 1089-1100. [CrossRef] [PubMed] 
22. Jasril, J.; Ikhtiarudin, I.; Hasti, S.; Reza, A.I.; Frimayanti, N. Microwave-assisted synthesis, in silico studies and in vivo evaluation for antidiabetic activity of new brominated pyrazoline analogs. TJPS 2019, 43, 83-89.

23. Zamri, A.; Teruna, H.Y.; Rahmawati, E.N.; Frimayanti, N.; Ikhtiarudin, I. Synthesis and in silico studies of a benzenesulfonyl curcumin analogue as a new anti dengue virus type 2 (DEN2) NS2B/NS3. Indonesian J. Pharm. 2019, 30, 84-90. [CrossRef]

(C) 2019 by the authors. Licensee MDPI, Basel, Switzerland. This article is an open access article distributed under the terms and conditions of the Creative Commons Attribution (CC BY) license (http://creativecommons.org/licenses/by/4.0/). 